\title{
PERSPEKTIF KOMUNIKASI KREATIF DI ERA DIGITAL OLEH STAKEHOLDER ILMU KOMUNIKASI UDINUS
}

\author{
Candra Yudha Satriya \\ Universitas Dian Nuswantoro Semarang \\ sateworld@gmail.com \\ Diajukan: 10-10-2019; Direview: 30-10-2019; Diterima: 11-12-2019;
}

\begin{abstract}
Evolving technologies continually present new opportunities and challenges for industry practitioners and academic researh. The information barrier automatically disappears by the strong initiative of individuals who want to know more about what is happening around them. This era full of values, ideas, concepts, creativity, and innovation requires unique, specific, and interesting competencies that communication science graduates must have in competing. The existence of social media strengthens the role of creativity for companies to be able to reach millennial audiences in an integrated and interactive manner through marketing communication strategies. This qualitative research further explores the effective implementation of the sustainable development of creative communication. Using semi-structured interviews and focus group discussions (FGD), identifying stakeholder perceptions in ensuring the sustainable development of creative communication in the digital age, especially in the communication science program of UDINUS. This research has solved the research problem, namely how communication industry stakeholders perceive, experience and practice creative communication in the digital age.
\end{abstract}

Keywords: Communication science, Creative communication, communication digital, Communication UDINUS

\begin{abstract}
Abstrak
Dominasi Teknologi Informasi dan Komunikasi, telah membuka lembaran baru dimana masyarakat bisa memperoleh informasi secara mandiri. Sekat-sekat informasi dengan sendirinya menghilang oleh inisiatif kuat individu yang ingin mengetahui lebih jauh apa yang terjadi sekitarnya. Era yang penuh akan muatan nilainilai ide, konsep, kreativitas, dan inovasi ini membutuhkan kompetensi unik, spesifik, dan menarik yang harus dimiliki sarjana ilmu komunikasi dalam berkompetisi. Keberadaan media sosial semakin memperkuat peran kreatifitas bagi perusahaan untuk bisa menjangkau khalayak milenial secara terintegrasi dan interaktif melalui strategi komunikasi pemasaran.Penelitian kualitatif ini mengeksplorasi lebih jauh implementasi yang efektif dari pengembangan berkelanjutan komunikasi kreatif. Menggunakan wawancara semi-terstruktur dan diskusi kelompok terarah (FGD), mengidentifikasi persepsi stakeholder dalam memastikan pengembangan berkelanjutan komunikasi kreatif di era digital pada program studi ilmu komunikasi UDINUS. Secara khusus penelitian ini telah menyelesaikan permasalahan penelitian yaitu Bagaimana stakeholder industri komunikasi mempersepsikan, mengalami dan mempraktikkan Komunikasi kreatif di era digital.
\end{abstract}

Kata kunci: Ilmu Komunikasi, Komunikasi kreatif, Komunikasi digital, Ilmu komunikasi UDINUS

\section{PENDAHULUAN}

$\mathrm{P}$ erkembangan dunia teknologi informasi yang demikian pesat telah membawa manfaat luar biasa bagi kemajuanperadaban manusia. Demikian halnya dengan yang terjadi di Industri komunikasi, yaitu terjadinya disrupsi sebagai akibat dari adanya evolusi teknologi. Digitalisasi sebagai dampak dari evolusi teknologi informasi yang mengubah hampir semua tatanan kehidupan sosial maupun ekonomi (Nilamsari, 2006). Berkembangnya industri konten digital pada media sosial seperti Instagram, Facebook dan Twitter ataupun platform lainnya termasuk Youtube, atau dalam industri media yaitu dengan adanya kehadiran news aggregator yang kemudian menghasilkan konten sendiri yang banyak dibaca 
oleh pengguna media seperti misalnya Line today. Keberadaan media sosial dan berbagai macam media online menjadi suatu keuntungan dalam keterbukaan dan kecepatan penyampaian informasi sehingga informasi akan semakin banyak tercipta.

Industri konten merupakan industri yang sangat menjanjikan dan berkembang. Ide kreatif terus dibutuhkan untuk bisa menjangkau khalayak milenial secara terintegrasi dan melibatkan peran marketing, PR, advertising, media, maupun media sosial, sehingga setiap perusahaan akan memastikan aspek komunikasi mereka bekerja secara efektif. Misalnya apabila kita membahas tentang industri komunikasi pemasaran yang terjadi dewasa ini, dulu para pemilik merek selalu berupaya mengagung-agungkan diri dalam setiap promosi. Mereka selalu tampil sebagai yang terhebat, termurah, tercepat, terbaik seakan tidak ada cacat. Pendekatan yang dilakukan cenderung secara vertikal, eksklusif dan individual. Tetapi sekarang pendekatan seperti itu sudah tidak cocok lagi. Perusahaan yang semakin bersifat horizontal, sosial, dan inklusiflah yang semakin dihargai. Apalagi dengan adanya internet, konsumen tidak lagi mudah tertipu dengan berbagai promosi karena mereka dapat dengan mudah mendapatkan begitu banyak informasi di internet (Kertajaya, 2017).

Industri berbasis kreatifitas sudah semakin populer, mengakibatkan banyak anak muda yang ingin bekerja kedalam dunia profesi dengan tingkat kreativitas dan kemandirian yang tinggi ini. Di Indonesia, seperti yang tertera di Creative economy outlook 2019 Bekraf, pembuat kebijakan percaya bahwa industri kreatif mempunyai potensi besar sebagai penyumbang PDB. Di negara-negara lain, terutama Amerika Serikat, keberhasilan industri kreatif dalam memberikan kontribusi yang sangat signifikan terhadap pertumbuhan ekonomi juga telah diakui. Hal yang sama juga terjadi di negaranegara Asia, misalnya Jepang, Cina ataupun Korea selatan. Keberhasilan itu telah mempromosikan dan membuat industri kreatif, khususnya industri hiburan, sebagai industri yang mendiversifikasi ekonomi mereka melalui strategi yang digerakkan pemerintah (Fung, 2016).

Untuk menghadapi era digitalisasi, Ilmu Komunikasi Universitas Dian Nuswantoro merupakan salah satu program studi yang mempunyai diferensiasi cukup jelas. Berbeda dengan kampus komunikasi lainnya, Udinus mewadahi komunikasi sebagai bagian dari Fakultas Ilmu Komputer (FIK). Seperti yang diketahui bersama, Ilmu komunikasi pada dasarnya adalah derivatif dari Fakultas Ilmu Sosial Politik di berbagai perguruan tinggi. Karenanya, sebagai sebuah ilmu turunan, ilmu komunikasi menjadi cabang ilmu relatif baru dalam proses pembentukannya serta masih membutuhkan dorongan ilmu lain agar menjadi salah satu cabang ilmu yang mapan dan kontributif. Di Udinus pendekatan ilmu komunikasi yang dilakukan adalah berbasis kemampuan teknologi informasi seperti yang tercantum pada visi program studi yaitu "Menjadi Program Studi Pilihan Utama Di Bidang Komunikasi Dengan Keunggulan Penguasaaan Kompetensi Komunikasi Berbasis Teknologi Informasi dan Creativepreneurship". Lulusan yang diharapkan merupakan Ahli komunikasi bisnis, yang terampil dalam perencanaan program komunikasi bisnis, komunikasi strategis, periklanan, pengelolaan event, dan pengembangan konten media kreatif yang mendukung aktivitas bisnis, dengan keahlian memanfaatkan teknologi informasi dan komunikasi (ICT).

Penelitian ini bertujuan untuk membedah bagaimana stakeholder Industri komunikasi mempersepsikan, mengalami dan mempraktikkan komunikasi kreatif di era digital. Oleh sebab itu, pertanyaan utama dari penelitian ini adalah sejauh mana konsep komunikasi kreatif di era digital dipahami dan diterima dalam industri komunikasi. Bagaimana perspektif stakehoder terhadap komunikasi kreatif di era digital, dimana perubahan teknologi telah mempengaruhi tingkat pendidikan dan kemampuan produksi dalam rantai produksi industri komunikasi. Serta dimana penggunaan luas internet dan digitalisasi komunikasi telah mengalami revolusi produksi dan konsumsi produk komunikasi. Selain itu, perubahan teknologi ini juga telah memburamkan batasan dari industri komunikasi ke produk industri kreatif lainnya, seperti social media dan iklan dan telah menghasilkan perubahan estetika serta keterampilan teknis yang diperlukan (Raugust, 2004). Stakeholder yang dimaksud pada penelitian ini adalah perusahaan-perusahaan di Industri 
Komunikasi. Sedangkan perusahaan yang menjadi subyek dari penelitian ini adalah perusahaan industri komunikasi yang mempunyai divisi atau fungsi komunikasi kreatif, sesuai dengan kompetensi lulusan ilmu komunikasi UDINUS.

\section{Komunikasi Kreatif di era digital}

Pada komunikasi strategis, Kreativitas dengan cepat menjadi kegiatan utama di dalam platform komunikasi, terlebih lagi konsumen mengharapkan lebih banyak pendekatan kreativitas dariperusahaan dalam ruang sosialnya (Mangold \& Faulds, 2009). Platform komunikasi kreatif seperti media sosial memungkinkan pengguna untuk mengumpulkan, menampilkan, dan membagikonten dengan orang lain. Pendekatan kreatif pada ilmu komunikasi mewakili sebuah cara baru memandang media dan konten hiburan sebagai suatu sistem di mana khalayak dan konsumen adalah bagian integral dari kesuksesan suatu strategi komunikasi perusahaan.Strategi komunikasi kreatif dimulai dengan mengidentifikasi tujuan bisnis, meneliti dan memahami audiens, dan menentukan apa yang kita inginkan untuk dipikirkan, dirasakan, dan dilakukan oleh audiens sebagai akibat dari berinteraksi dengan konten kita. Strategi tersebut mempertimbangkan taktik terbaik untuk mencapai tindakan dan perilaku yang diinginkan, dan kemudian menyajikan taktik tersebut dengan cara yang paling menarik bagi audiens. Penekanannya adalah pada penggunaan kreativitas dan inovasi untuk mengejutkan dan menyenangkan audiens (VTLI, 2019).

Seiring perkembangan teknologi, mengubah perilaku khalayak dalam melakukan interaksi dan transaksi, mulai dari pencarian informasi sampai penyampaian feedback, bahkan referensi. Internet sudah tidak bisa dipungkiri menjadi ancaman dan peluang serius bagi perusahaan. Oleh karena itu, dalam menentukan strategi tidak lagi bisa berdasarkan intuisi belaka, melainkan berdasarkan data. Dengan adanya big data, analisis sederhana tidak cukup lagi mengekstrak faktafakta khalayak dalam bentuk insight yang penting. Kumpulan data tersebut diserap, dikomunikasikan, digabungkan, disimpan dan dianalisis. Big data muncul akibat berkembangnya aktivitas ekonomi modern, inovasi, pertumbuhan berbagai sektor, dan perubahan teknologi (Kertajaya, 2013).

Meningkatnya teknologi digital dan pemasaran online sejak pertengahan 1990-an, iklan berbasis internet adalah pengeluaran iklan dengan pertumbuhan tercepat kategori mendatang, melampaui TV, radio, dan lainnya. Di Indonesia, pertumbuhan tahunan gabungan belanja iklan di televisi tumbuh 14,5\% sejak 2014 hingga 2017. Sementara belanja iklan secara online tumbuh $44,3 \%$ untuk periode yang sama. (www.katadata. co.id). Dari situ kita bisa melihat format media tradisional dengan Web 2.0 dan konsep media baru melalui internet telah memasuki periode apa yang disebut sebagai budaya partisipatif, di mana luaran media baru dibuat disesuaikan dan sering berkolaborasi dengan khalayak. Pembuat konten memiliki koneksi yang sangat intim dengan audiens mereka, terutama dengan generasi milenial, yang telah tumbuh dengan internet dan secara intuitif memahami distribusi digital dan nilai yang dimilikinya.

Hermawan menyebut era ini sebagai era komunikasi 4.0 yaitu Era Omnichannel experience, yang menjadikan pendekatan komunikasi dengan mengkombinasikan interaksi online dan offline sebagai tujuan utama untuk memenangkan advokasi khalayak. Semakin berkembangnya teknologikomunikasi digital, digital interaksi saja tidak cukup. Bahkan, semakin dunia online berkembang, sentuhan offline justru menjadi sebuah diferensiasi yang kuat. Komunikasi 4.0 ini juga membutuhkan kreatifitas untuk memadukan gaya dengan substansi. Meskipun sangat penting bagi perusahaan untuk menjadi lebih fleksibel dan adaptif karena tren teknologi yang cepat, tetapi karakter mereka yang otentik adalah lebih penting. Dalam dunia yang semakin transparan, otentisitas merupakan aset yang paling berharga. Komunikasi 4.0 juga mengembangkan konektivitas machineto-machine dan artificial intelligence dalam rangka mendongkrak produktivitas. Tetapi, itu harus diimbangi dengan pengembangkan konektivitas human-to-human yang justru akan memperkuat customer engagement. Intinya, pengembangan teknologi tidak berhenti pada teknologi itu sendiri, tapi bagaimana teknologi ini membantu perusahaan dalam memanusiakan relasi dengan para khalayaknya (Kertajaya, 2016). 


\section{Peran Media Sosial pada Komunikasi kreatif}

Penelitian ini secara langsung melakukan validasi dengan para pelaku industri komunikasi, dan bertujuan untuk mengidentifikasi kebutuhan ketrampilan komunikasi pemasaran digital. Penelitian terdahulu tentang media sosial mengidentifikasi perlunya eksplorasi akademik lebih lanjut yang berfokus pada penggunaan media sosial untuk komunikasi pemasaran (Akar \& Topcu, 2011; Bradyet al., 2008) sehingga menutup kesenjangan yang dirasakan antara industri dan akademisi di bidang komunikasi pemasaran. Banyak perubahan di bidang komunikasi telah dievolusikan dalam rangka merespon digitalisasi. Misalnya, seringkali pemasar bereksperimen melalui uji ide-ide baru di Facebook, sehingga bisa mengumpulkan umpan balik lebih cepat dan lebih banyak, daripada memilih untuk melakukan kelompok diskusi FGD (Brynjolfsson \& Schrage, 2009) atau pendekatan risettradisional lainnya (Mulhern, 2009) ). Perubahan terbesar yang telah dipengaruhi oleh pesatnya perkembangan teknologi Web2.0 adalah munculnya media sosial yang memungkinkan terciptanya "sungai" informasi (Day, 2011; Klingberg, 2009; Micu et al., 2011) di mana organisasi bisnis ataupun individu bisa mempromosikan produk, layanan, opini, ulasan serta blog, sehingga memungkinkan terciptanya banyak aliran informasi.

Micu (2011) mencatat bahwa sekitar 80\% dari masalah komunikasi pemasaran saat ini ditangani dengan melakukan riset pemasaran.Kedepan, perusahaan paling maju adalah perusahaan yang mampu mengembangkan teknologi dan SDM untuk menangkap aliran "sungai" informasi (Micu, 2011, hlm. 215). Penelitian lainnya oleh McAfee dan Brynjolfsson (2012) menyoroti beberapa kesulitan yang terkait dengan interpretasi bigdata. Penelitian tersebut menguraikan hambatan manajemen perubahan yang efektif yang tersaji daribig data yaitu: kegagalan kepemimpinan, kurangnya SDM yang tepat, kegagalan mengadopsi teknologi baru, pengambilan keputusan dan budaya perusahaan yang tidak sepenuhnya mendukung pendekatan berbasis data. Hal ini sejalan dengan penelitian ini, yaitu adanya profesi komunikasi yang berfokus pada kurangnya kemampuan teknis pada karyawan dan kurangnya strategi digital secara keseluruhan. Micu (2011,hal.219) juga mencatat adanya kebutuhan pengembangan keterampilan data miningkomunikasi pemasaran untuk mengeksplorasi, mencerna, mensintesis dan menjelaskan, sehingga keterampilan komunikasi dan mendongeng adalah penting bagi pemasar.

Strategi komunikasi pemasaran yang sukses akan secara jelasmencerminkan nilainilai yang diartikulasikan dalam pernyataan misidan berkontribusi untuk pemenuhantujuan kinerja perusahaan. Untuk mencapai tujuan tersebut, elemen-elemen promotion mix dikoordinasikan dengan hati-hati sehingga informasinyaditransmisikan ke pasar melalui elemen-elemen ini secara konsisten mengkomunikasikan pesan terpaduyang secara luas mencerminkan nilai-nilai fundamental perusahaan. Misalnya saja upaya promosi yang dilakukan oleh Pupuk Indonesia (PI) yang mengilustrasikan nilainilai yang mendasari organisasi ini sebagaimana diartikulasikan dalam pernyataan visi misi dan pernyataan prinsip strategis(Pupuk Indonesia, 2018). Ketika organisasi tersebut memasuki arena media sosial, mereka dengan hati-hati menyusun komunikasi mereka dengan pasar untuk secara konsisten mencerminkan nilai-nilai organisasi mereka. Dengan melakukan itu, PI mengakui pentingnya memasukkan media sosial ke dalam strategi komunikasi mereka. PI menunjukkan bahwa penggunaan media sosialmemiliki dua peran yang saling terkait yaitu pertama, media sosial memungkinkanperusahaan untuk berbicara dengan pelanggan mereka. Dan yang kedua, Media sosial memungkinkan pelanggan untuk berbicara satu sama lain, serta memungkinkan pelanggan untuk berbicara dengan perusahaan.

\section{Kesenjangan ketrampilan komunikasi kreatif dalam Industri Komunikasi}

Sangat menarik untuk dicatat bahwa Lace (2004) (dalam Valos et al., 2010) menemukan hanya setengah dari pelaku industri komunikasi di Inggris merasa strategi integrasi media digital mereka berhasil. Jadi 50\% praktisi komunikasi di 
Inggris merasa strategi yang dilakukannya tidak efektif. Sedangkan Michaelidou dan Siamagka (2011) menemukan dalam studi mereka tentang penggunaan media sosial seperti Facebook, Twitter dan LinkedIn adalah media sosial yang paling populer digunakan, terutama untuk menarik pelanggan baru dan menjalin hubungan. Namun, hambatanyang terjadiadalah banyak pelakuindustri komunikasi yang meyakini ketidakefektifan media sosial, dan juga tidak paham bagaimana media sosial dapat meningkatkan strategi komunikasi. Selain itu, penelitian itu juga menyebutkan bahwa karyawan tidak merasa akrab dengan media sosial dan tidak memiliki keterampilan teknis untuk menggunakannya.

Quinton dan Fennemore (2013) meneliti penggunaan media sosial, seperti Facebook dan Twitter, dan menemukan bahwa hambatan untuk menggunakan termasuk kurangnya sumber daya dan keterampilan pemasaran media sosial. Demikian pula, Mulhern (2009) mencatat bahwa ketika serangan teknologi digital menimbulkan tantangan besar bagi industri komunikasi, pemasar tidak memiliki pola pikir dan keahlian teknis untuk mengatasi tantangan tersebut. Jarvinen,Toll inen,Karjaluoto,Jayawardhena (2012) dalam studi mereka tentang adopsi media sosial, menemukan bahwa masih ada tendensi industri komunikasi yang masihberfokus pada metode komunikasi satu arah dengan memanfaatkan alat digital yang ada, karena mereka tidak memiliki sumber daya manusia dan pengetahuan untuk mengeksploitasi media sosial.

Pandangan para peneliti diatas mengindikasikan adanya gap atau kesenjangan keterampilan komunikasi, tetapi realitasnya masih belum dijelaskan secara detail tentang apa sebenarnya kesenjangan keterampilan. Selain itu, tidak ada fokus khusus pada kesenjangan keterampilan dalam industri komunikasi. Akan sangat membantu jika bisa dirinci jenis keterampilan komunikasi kreatif yang diperlukan dalam industri dan bagaimana keterampilan tersebut meningkatkan pendekatan komunikasi pemasaran. Keterampilan seperti mengonstruksi situs web, memaksimalkan potensi media sosial seperti Facebook dan Twitter, Search
Engine Optimization (SEO), aplikasi seluler, konversi pelanggan dan pengetahuan analitik digital untuk mengevaluasi efektivitas pendekatan digitaladalah di antara banyak keterampilan komunikasi pemasaran digital yang paling penting. Tanpa keterampilan tersebut, industri berada pada kondisi kerugian kompetitif, karena mereka kehilangan kemampuan untuk terhubung dan berkomunikasi secara cepat dengan klien (media sosial); mereka tidak dapat menerjemahkan kunjungan atau pembelian klien ke situs web (konversi pelanggan) dan mereka mungkin tidak dapat mengevaluasi pendekatan digital mana yang paling efektif untuk bisnis mereka (analitik).

Oleh karena itu, diperlukan ahli strategi kreatif untuk memahami sifat komunikasi pemasaran digital yang saling melengkapi dan cara terbaik untuk mengimplementasikannya, terutama ketika beberapa pendekatan digital digunakan secara bersamaan. Para profesional komunikasi yang diwawancarai pada penelitian ini mengkonfirmasi bahwa terdapat kesenjangan keterampilan pemasaran digital, dan juga membenarkan adanya kekurangan keterampilan teknis. Secara khusus, penelitian ini menemukan celah dalam keterampilan SEO, seluler, blog dan komunikasi online termasuk pemanfaatanbroadcast messages dan alat-alat media sosial secara maksimal.

\section{Tenaga Kerja di Industri Komunikasi dan kreatif}

Penelitian,pengembangan, pendidikan, pelatihan, dan pembelajaran di tempat kerja dapat membuat suatu daerah menjadi sumber difusi pengetahuan. Karena itu, suatu bangsa atau wilayah dengan tingkat modal SDM yang tinggi dapat meningkatkan pengembangan teknologi, sebagai faktor penting pertumbuhan ekonomi regional. Secara keseluruhan, wilayah tersebut cenderung mempunyai daya saing yang tinggi dan menjadi lebih mampu memberikan layanan bernilai tambah. Dengan demikian, negara-negara berkembang seperti Indonesia, dapat meningkatkan pertumbuhan ekonomi denganmenghasilkantenaga kerja yang berkualitas tinggi melalui peningkatan pendidikan dan pelatihan pada industri berbasis pengetahuan, misalnya industri kreatif (Cheshire 
dan Malecki, 2004). Karakteristik tenaga kerja pada industri kreatif sering dihubungkan dengan kata-kata yang berkonotasi seperti kesenian, pengetahuan, dan kemewahan (Hesmondhalgh dan Baker, 2008, 102) dikarenakan sifat produksi hasil budaya sudah tertanam kuat sebagai nilai estetika dan pengetahuan simbolik. Karakteristik industri kreatif ini sering dipahami sebagai pekerjaan yang menghasilkan penghargaan tinggi dan bergaji tinggi. Oleh karena itu, orang-orang yang bekerja dalam industri kreatif dibayangkan sebagai profesional berpendidikan tinggi bukan sebagai buruh manual atau wirausaha mandiri.

Di lain sisi, bekerja sebagai pekerja komunikasi kreatif di sebuah perusahaan, secara langsung merupakan karyawan pada proses produksi sehingga mau tidak mau pengusaha memiliki kekuasaan yang kuat atas karyawan tersebut. Dengan kata lain, pekerja individu dipastikan menjadi kurang otonom dan mandiri untuk mengatur diri sendiri. Di bawah kapitalisme, kreatifitas telah menjadi komoditas yang harus menciptakan nilai, dan pekerja yang terlibat dalam produksi karya kreatif menjadi bagian eksklusif perusahaan yang mempunyai tugas khusus, berada pada lingkungan dengan intensitas tinggi dan terisolasi (Banks, 2010). Keahlian tidak lagi dianggap lambang pencapaian karir di industri kreatif; alih-alih harus cukup efisien untuk menciptakan nilai dalam sistem produksi massal.

Pada dasarnya, Industri Kreatif berhubungan dengan ide dan uang, dimana imajinasi dan kreativitas menentukan apa yang orang-orang ingin lakukan dan hasilkan". Adalah paradigma ekonomi baru yang mengandalkan gagasan, ide, atau kreativititas dari SDM sebagai faktor produksi utama dalam kegiatan ekonominya. Sumber daya utama dalam Industri Kreatif adalah kreativitas, yakni kapasitas atau kemampuan untuk menghasilkan atau menciptakan sesuatu yang unik, solusi dari suatu masalah, atau sesuatu yang berbeda dari pakem. Namun selain kreativitas, unsur lain yang dianggap penting untuk menunjang Industri Kreatif adalah nilai tambah. Nilai tambah ini dapat dilihat dari adanya peningkatan kualitas produk dari segi nilai dan ekonomi. Kegiatan seperti hobi yang dilakukan secara cuma-cuma belum bisa digolongkan ke dalam Ekonomi Kreatif
(Bekraf, 2018).

Sekarang adalah era dimana peluang terlihat sempit pada bidang aplikasi ilmu konvensional, namun sangat terbuka lebar dengan tak terbatasnya peluang ilmu komunikasi penyokong industri kreatif. Saatnya bagi sarjana komunikasi menjadi pemain utama dalam industri komunikasi kreatif, terutama bagi lulusan Ilmu Komunikasi Udinus, sesuai dengan visi program studi yang mengedepankan kreativitas dan kewirausahaan. Lulusan komunikasi era sekarang, dituntut untuk mempunyai mindset yang berbeda dan mau melakukan perubahan menyesuaikan jaman. Pekerjaan sebagai Jurnalis, humas, iklan, manajemen komunikasi dan lainya sudah tidak terlihat menjanjikan. Namun, di sisi lain, ada ratusan hingga ribuan startup se-Indonesia yang memerlukan sentuhan skills spesifik lulusan komunikasi. Dengan rata-rata pendiri startup tersebut berlatar teknik informatika, maka mereka pasti perlu mitra yang memahami startegi komunikasi. Terlebih lagi, merujuk data Bekraf di tahun 2017, peluang juga terbuka lebar selain usaha rintisan digital, juga pada bidang ekonomi kreatif dengan serapan terbesar yakni kuliner sebesar $41,69 \%$, Kriya sebesar $15,70 \%$ dan fesyen sebesar 18,15\%, dilanjutkan di tahun 2018, ada 4 dari 16 subsektor Ekonomi Kreatif berpotensi menjadi kekuatan ekonomi baru yakni film, musik, art, dan game (animasi). Empat subsektor ini memiliki nilai pertumbuhan ekonomi yang paling pesat. Disinilah peluang terbesar dari ilmu komunikasi untuk semakin aktual dan diperlukan terutama untuk ranah implementasi ilmu berbasis new media dan ekonomi kreatif.

\section{LITERATUR DAN METODOLOGI}

Penelitian ini mengadopsi Komunikasi Kreatif di era digital sebagai kerangka kerja konseptual untuk menganalisis bagaimana konsep komunikasi kreatif yang selama ini dipahami dan diturunkan sebagai mata kuliah-mata kuliah di perkuliahan ilmu komunikasi Universitas Dian Nuswantoro Semarang sesuai dengan kebutuhan industri komunikasi.Apakah dengan perkembangan teknologi dan digital, universitas perlu meninjau kembali pendekatan pengajaran komunikasi 
kreatif.Atau apakah teknologi baru mempengaruhi kurikulum pendidikan ilmu komunikasi maupun alat yang digunakan untuk mengajarkan kurikulum itu. Penelitian sebelumnya juga menjelaskan bahwa budaya lembaga akademik dapat didorong oleh perubahan yang terjadi pada lingkungan bisnis eksternal (Grant, Hackney, \& Edgar, 2009, hal. 152).

Oleh sebab itu, perlu adanya kesesuaian antara kebutuhan ketrampilan komunikasi kreatifdi indutri komunikasi dengan profil lulusan universitas. Ketika kebutuhan tersebut berubahmaka keterampilan yang dibutuhkan dalam industri komunikasi juga akan menyesuaikan. Peningkatan penggunaanketerampilaninimengubahpendekatan industri dan akademik di setiap disiplin ilmu yang menyertai. Dari penelitian sebelumnya, ada perubahan mendasar dari pendekatan pengajaran komunikasi pemasaran di pendidikan tinggi, yang menunjukkan bahwa perkembangan digital harus menjadi pusat pengajaran dan penelitian dalam komunikasi pemasaran, dibanding hanya sebagai pelengkap atau tambahan (Wymbs, 2011). Bahkan muncul pula pengakuan bahwa revolusi digital pada dasarnya mengubah esensi komunikasi pemasaran secara keseluruhan (Wymbs, 2011, hal 95). Akibatnya, kebutuhan akan lulusan komunikasi yang melek digital menjadi lebih mendesak.

Penelitian ini menggunakan desain penelitian kualitatif untuk mengeksplorasi bagaimana konsep komunikasi kreatif dipahami dan diresapi dalam perusahaan industri kreatifdi Semarang dari perspektif stakeholder. Hal tersebut menjadi penting mengingat keberadaan lulusan komunikasi dituntut untuk mempunyai kemampuan kreatif di dalam memecahkan persoalan-persoalan komunikasi di era digital. Konsistensi yang melekat antara logika win-win dan menghargai bahwa akademisi perlu melibatkan pemangku kepentingan sebagai strategi yang bermanfaat bagi Universitas untuk memenuhi tanggung jawab sosialnya. Sehingga desain penelitian kualitatif digunakan untuk mencapai tujuan dari penelitian ini. Seperti yang ditunjukkan oleh Creswell (1994), desain penelitian kualitatif adalah "suatu proses penyelidikan memahami masalah sosial atau manusia, yang didasarkan pada membangun gambaran holistik yang kompleks, terbentuk secara naratif, dan melaporkan secara terperinci dari informan yang dilakukan secara alamiah.

Secara khusus, pertanyaan wawancara semi-terstruktur dan diskusi kelompok terarah (FGD) digunakan sebagai pengumpulan data primer. Manajer Hubungan Masyarakat dari dua perusahaan korporasi BUMN skala nasional, serta dua 2 profesional pelaku media baru diwawancarai. Selain itu, ada 13stakeholder penting dalam industri komunikasi, yang dipilih secara purposive berdasarkan pengetahuan dan pengalaman mereka tentang komunikasi kreatif, dan kemudian melakukan FGD. Dengan izin dari responden wawancara dan sesi FGD, audio-visual perekam digunakan untuk merekam percakapan. Ini ditranskripsi kata demi kata dan transkripnya kemudian dibaca berulang kali bersamaan dengan kaset audio-visual untuk memastikan keandalan dan validitas data. Juga, data diberi kode dan dimasukkan ke dalam kategori yang relevan dan Tema yang muncul kemudian dianalisis. Kutipan langsung digunakan, jika perlu, untuk mendukung tema. Kegiatan FGD dilakukan dengan mempertemukan pelaku industri komunikasi kreatif di enam sektor, yaitu film/animasi, desain komunikasi visual, aplikasi, musik, periklanan, fotografi sertaTV dan Radio. Pelaksanaan FGD ini dilakukan di Gedung $\mathrm{H}$ Universitas Dian Nuswantoro Semarang.

\section{TEMUAN DAN DISKUSI}

Tujuan dari penelitian ini adalah untuk mengetahui bagaimana stakeholderIndustri komunikasimempersepsikan, mengalami dan mempraktikkan komunikasi kreatif di era digital. Data yang dikumpulkansebagian besar mencakup pandangan, persepsi, dan pengalaman para pemangku kepentinganmelalui wawancara dan FGD. Yang terdiri dari informasi sukarela oleh 3 pria dan 1 wanita yang diwawancarai (tabel 1) dan 11 pria dan 2 wanita yang ikut berpartisipasi sebagai peserta FGD (tabel 2). Analisis data yang dikumpulkan mengikuti proses dua langkah. Pertama, file audio dan transkrip yang menyertainya 
Tabel 1. Daftar Partisipan Interview

\begin{tabular}{llll}
\hline Partisipan & Sex & Age & Kompetensi Komunikasi Kreatif \\
\hline Faisal Alfa Rocky & L & 36 & Public Relations PT Petrokimia Gresik \\
\hline Risza Maulana & L & 45 & Humas PT Pupuk Indonesia (holding). \\
\hline Okta Wiguna & L & 41 & Content \& Editorial Lead at LINE Indonesia \\
\hline Cania Kanza & P & 28 & Marcomm specialist Narasi TV \\
\hline \multicolumn{3}{c}{ Sumber: Data Peneliti, 2019 }
\end{tabular}

masing-masing didengarkan dan dibaca beberapa kali. Kemudian, kedua, menghadirkan kedua perbedaan dan kesamaan pandangan yang diungkapkan oleh semua pemangku kepentingan lalu merinci sudut pandang spesifik pada setiap pemangku kepentingan.

Dari hasil wawancara dan FGD, semua profesional industri komunikasi sepakat bahwa komunikasi kreatif adalah bagian yang tumbuh menyertai layanan atau bisnis yang mereka lakukan, terutama karena adopsi media sosial yang tersebar luas seperti Twitter, Facebook, Instagram, dan YouTube di antara masyarakat. Budaya generasi milenial sekarang sudah menjadi sebab nyata digunakannya komunikasi kreatif, dengan mengintegrasikan komunikasi secara online dan offline demi terciptanya interaktifitas. Untuk mengantisipasi perubahan budaya tersebut, ada sejumlah pendekatan digital lain yang digunakan, mulai dari gencar melakukan promosi di media sosial, memperlakukan media sosial sebagai cara untuk mengikat pelanggan sampai menyebarkan informasi melalui digital broadcast. Strategi komunikasi kreatif ini sering menavigasi pemasaragar memanfaatkan media sosial untuk mendukung website, dan banyak profesional komunikasi menyebutkan bahwa situs web mereka sebagai titik awal inti, atau rumah dari bisnis digital mereka. Sepeti yang dilakukan oleh Folka creative, milea.id dan juga SODCA, yang memang berkonsentrasi mengembangkan bisnisnya melalui ruang-ruang di dunia maya.

Dari data FGD dijelaskan bahwa perkembangan teknologi digital yang berkelanjutan telah mengubah lansekap industri komunikasi secara keseluruhan, dan berpotensi menghadirkan peluang dan tantangan baru bagi komunikator beserta klien mereka. Selain kemampuan untuk berkomunikasi secara konvensional, juga dibutuhkan kemampuan berkomunikasi secara digital. Ada kebutuhan untuk memadukan kemampuan komunikasi terintegrasi, baik offline maupun online.Iswidodo dari Tribun juga menegaskan 'Bahkan kalau kami mau merekrut calon presenter juga tanya punya facebook gak temennya berapa. Harus dua ribu ke atas berarti dia aktif. Jadi media sosial harus begitu wartawan kuper gitu gak boleh, harus ikut grup sana grup sini dan lain sebagainya harus tahu bahkan ada info info kan ada yang melalui media sosial daripada di media mainstream".

Tabel 2. Daftar Peserta FGD

\begin{tabular}{llll}
\hline Partisipan & Sex & Age & Kompetensi Komunikasi Kreatif \\
\hline Hero Misdayadi & L & 38 & Owner Herosoft Digital Marketing \\
\hline Iswidodo & L & 45 & Redaktur Pelaksana Tribun Jateng \\
\hline Fitri & P & 26 & Program Producer TVKU \\
\hline Irfan & L & 33 & Owner IS creative \\
\hline Bernath Surya & L & 30 & Milea.id creative communication \\
\hline Benny Novareza & L & 28 & Program producer TraxFM Radio \\
\hline Fajar & L & 23 & Alumni Ilmu Komunikasi Udinus \\
\hline Septi Aji & L & 26 & SODCA design \\
\hline Aggia Hesibuan & L & 28 & Station head Metro TV \\
\hline M Mirza Firdaus & L & 29 & Owner Folka Creative \\
\hline Setya Utama & L & 28 & Head of Pura Creative Design \\
\hline Heri Santosa & L & 37 & Content head Radio Idola \\
\hline Nurhasanah & P & 52 & Wakil ketua P3I Jateng \\
\hline & \multicolumn{2}{c}{ Sumber: Data Peneliti, 2019 }
\end{tabular}


Sebagaikomunikator kreatif, selain kemampuan untuk mengelola strategi komunikasi konvensional, juga dibutuhkan kemampuan komprehensif tentang strategi komunikasi pemasaran digital dari perencanaan sampai evaluasi.

"Jadi digital marketing tapi juga membutuhkan analisa, di data analis itu jelas sangat dibutuhkan sekali, facebook lah instragram dan segala macem google analitik segala macem, ya itu tool itu sangat mudah dipelajari, asalkan seseorang tau menerjamahkan data sebagai sebuah voice, ya itu analisa atau seolah-olah data ya ini kita berbicara sedikit tentang analisis juga sangat dibutuhkan, lalu juga membutuhkan erendi yang tidak dibutuhkan cepat, tapi juga dibutuhkan skill tasting yang mana sebenarnya factor yang ada mana yang lebih berbobot mana yang lebih penting mana yang lebih berdampak besar itu, sangat dibutuhkan didunia digital." CEO herosoft

Kesenjangan keterampilan komunikasi kreatif paling signifikan yang muncul dari penelitian ini adalah kesulitan industri dalam menemukan karyawan dengan pengetahuan strategis tentang komunikasi pemasaran digital sebagai jantung dari kemampuan komunikasi kreatif, yang kemudian dapat mengintegrasikannya dengan pendekatan komunikasi pemasaran tradisional, sehingga bisa melakukan kegiatan-kegiatan pendekatan komunikasikreatifdengan mengkombinasikan interaksi online dan offlinesebagai tujuan utama untuk memenangkan advokasi khalayak offline (Kertajaya, 2013) .

Dari masukan CEO Herosoft tersebut menunjukan perlunya pendekatan yang terintegrasi secara cerdas, yang diamini oleh peserta FGD lainnya, yang merasa bahwa perlu adanya usaha akademisi untuk bisa menutup kesenjangan keterampilan yang ada antara pengetahuanteknis dan pengetahuan bisnis. Kesenjangan keterampilan pasar komunikasi kreatif ini muncul sebagai tantangan terbesar yang dihadapi industri, antara lain keterampilan yang berfokus pada teknis pengoptimalan mesin pencari SEO, pengetahuan aplikasi seluler, keahlian video ataupun animasi, serta kemampuan yang paling urgent adalah kemampuan untuk menerapkan dan mengintegrasikan strategi pemasaran digital dengan pengetahuan teknis dan landasan komunikasi strategis, misalnya berupa keterampilan komunikasi pemasaran digital yang terintegrasi dengankomunikasi pemasaran tradisional termasuk media cetak serta media luar ruang.

Dari hasil wawancara juga menyimpulkan bahwa Integrasi perencanaan media dan penyelarasan aktivitas terkait (Kaplan \& Haenlein, 2010) adalah salah satu kunci dari keterampilan pemasaran digital dan hal tersebut sebagian besar didorong oleh kurangnya karyawan yang tersedia dengan pengetahuan digital serta kemampuan teknis yang strategis.Seperti kata Faisal Alfa "bagaimana kita mengatur yang namanya digital campaign, memanfaatkan teknologi digital di dalam berkomunikasi dan menjadikannya sebagai tools dalam kePRan perusahaan. Selanjutnya adalah kemampuan softskill yang dibutuhkan adalah lulusan komunikasi itu harus mempunyai kemampuan untuk menjadi content creator, baik itu di bidang video, foto maupun text." Kemudian untuk integrasi komunikasi digital dengan pendekatan komunikasi tradisional (Kertajaya, 2013) dibutuhkan personel yang memiliki keterampilan yang tepat, ada kemungkinan bahwa pendekatan yang serampangan terhadap integrasi akan terjadi. Kurangnya integrasi strategis ini berkontribusi terhadap kecenderungan banyak perusahaan mengadopsi pendekatan learning by doing (Brynjolfsson \& Schrage, 2009).

Penelitian ini juga telah mengidentifikasi tantangan yang melekat pada teknologi digital (familiaritas dengan aplikasi mobile, analisis SEO, mengembangkan praktik metrik terbaik, menggunakan blog dan grup diskusi online) terkait dengan kesenjangan dalam keahliankomunikasi kreatif. Kung (2008). Dibutuhkan keterampilan yang relevan dengan domain bidang keahlian baru dalam ranah komunikasi pemasaran. Pemasar harus menguasai bidang produk baru yang melibatkan berbagai jenis konten dan kompetensi konten yang berbeda.

"Harus memiliki skil-skil penyusunan publikasi, maksudnya seperti ini, sudah maklum atau sudah mahfum di dunia PR itu yang namanya website, konten websitenya ya bukan programmingnya, kemudian juga publikasi seperti majalah, kemudian juga media sosialnya dia harus bisa menguasai 
minimal mempunyai pengalaman untuk menyusun membuat menulis suatau karya tulis, karya tulisnya ini pun harus yang mempunyai nilai-nilai yang jika dibaca tidak membosankan, menarik pembaca, ada isinya segala macam tuh." Humas PT Pupuk Indonesia

Pendekatan yang lebih holistik yang mengintegrasikan teknologi digital dengan prinsip-prinsip komunikasi tradisional memang sangat diperlukan demi terciptanya kesuksesan komunikasi kreatif (Crush, 2011).

\section{SIMPULAN}

Penelitian ini membedah bagaimana stakeholder Industri komunikasi mempersepsikan, mengalami dan mempraktikkan komunikasi kreatif. Dari hasil penelitian ditegaskan bahwa para stakeholder mempersepsikan peran komunikasi digital semakindominan bagi kesuksesan strategi komunikasi kreatif. Digital yang dulunya hanya sebagai pelengkap, sekarang menjadi semakin krusial. Kemampuan menerjemahkan strategi komunikasi melalui pemanfaat dunia maya menjadi hal yang tidak bisa dipungkiri. Oleh sebab itu, menjadi masukan yang harus diprioritaskan untuk menyesuaikan kurikulumilmu Komunikasi Universitas Dian Nuswantoro. Selainitu, ditemukan bahwa masalah utama yang dihadapi industri komunikasi adalah kurangnya pendekatan strategi terintegrasiuntuk komunikasikreatif.Tantangan pendekatan terintegrasi untuk strategi komunikasi pemasaran bukanlah hal yang baru (Valos et al., 2010) dan teknologi yang berkembang pesat menjadikan masalah ini akan tetap terjadi (Akar \& Topcu, 2011; Brady et al., 2008). Kurangnya pedoman praktik komunikasi terbaik mengarah pada pendekatan learning by doingberdasarkan eksperimen. Perlu dibuat sebuah pedoman berbasis bukti tentang praktik terbaik komunikasi kreatif sehingga akan menghilangkan sebagian risiko yang melekat dalam pendekatan eksperimental.

Penelitian lanjutan dibutuhkan untuk mengidentifikasi pendekatan praktis terbaik, misalnya tentang teknis pengelolaan media sosial, dsb. Ada tantangan individu yang dihadapi profesional sektor publik dan swasta karena perbedaan penggunaan media sosial dan pemasaran digital, sementara sektor swasta terutama mengadopsi pemasaran digitalsebagai saluran komunikasi untuk mempromosikan dan menjual produk dan layanan untuk klien, penggunaan sektor publik terutama difokuskan pada berbagi informasi dan mendorong pengelolaan pengguna. Mengantisipasi adopsi keterampilan pemasaran digital di masa depan menyebabkan banyak diskusi di antara para profesional komunikasi. Para praktisi komunikasi yang berpartisipasi dalam penelitian ini berfokus pada mengatasi tantangan komunikasi kreatif secara langsung. Meski banyak kekurangan, penelitian ini menguraikan keterampilan dan kompetensi yang diperlukan oleh pelaku komunikasi kreatif yang ideal. Dengan mendengarkan kebutuhan pemasar dan menangani masalah yang relevan dengan industri komunikasi, penelitian ini telah memberikan masukan yang dapat digunakan sebagai pertimbangan akademisi untuk menyusun kurikulum, serta bisa dianggap sebagai panduan untuk pengembangan keterampilan para pelaku industri komunikasi.

\section{DAFTAR PUSTAKA}

Akar, E., \& Topcu, B. (2011). An examination of the factors influencing consumers'attitudes toward social media marketing. Journal of Internet Commerce, 10,35-67.

Banks, M., 2010. Craft labour and creative industries. Int. J. Cultural Pol. 16 (3)350 321.

Bekraf, (2017). Tenaga Kerja Ekonomi Kreatif 2011-2016Jakarta, Indonesia

Bekraf, (2015). Rencana strategis Badan Ekonomi Kreatif 2015-2019Jakarta, Indonesia

Brady, M., Fellenz, M. R., \& Brookes, R. (2008). Researching the role of information andcommunications technology (ICT) in contemporary marketing practices. Journalof Business and Industrial Marketing, 23(2), 108-114.

Brynjolfsson, E., \& Schrage, M. (2009). The new, faster face of innovation: Thanks totechnology, change has never been so easy-or so cheap. Wall Street Journal and Sloan Management Review,. Accessed 12.11.11.

Cheshire, P., Malecki, E., 2004. Growth, 
development, and innovation: a look backward and forward. Papers Regional Sci. 83 (1), 249-267.

Creswell, J. W. (2003). Research design (2nd ed.). London: Sage

Creswell, J. W. (1994). Qualitative and quantitative approaches. Thousand Oaks, CA: Sage.

Crush, P. (2011). Filling the digital skills gap. Marketing, 13 July, 33-34.

Day, G. S. (2011). Closing the marketing capabilities gap. Journal of Marketing, 75,183-195.

Fast, K., Ornebring, H., Karlsson, M., (2016). Metaphors of free labor: a typology of unpaid work in the media sector. Med. Cult. Soc. 38 (7), 963-978.

Fung, A., 2016. Redefining creative labor: East Asian comparisons. In: Curtin, M., Sanson,K. (Eds.), Precarious Creativity: Global Media, Local Labor. University of California Press, Oakland, California, pp. 200-214.

Grant, K. M., Hackney, R., \& Edgar, D. (2009). Informing UK information management pedagogic practice: The nature of contemporary higher education culture. International Journal of Information Management, 30(2), 152-161.

Hamill, J., Tagg, S., Stevenson, A., \& Vescovi, T. (2010). Editorial: Special edition Newdevelopments in online marketing. Journal of Marketing Management, 26(34),181-186.

Hesmondhalgh, D., Baker, S., 2008. Creative work and emotional labour in the television industry. Theory Culture Soc. 25 (7-8), 97-118.

Hoffman, D. L., \& Novak, T. P. (2011). Marketing communication in a digital era.Marketing Management, 20(3), 36-43.

Jarvinen, J., Tollinen, A., Karjaluoto, H., \& Jayawardhena, C. (2012). Digital and socialmedia marketing usage in $\mathrm{N} 2 \mathrm{~N}$ industrial section. Marketing Management Jour-nal, 22(2), 102-117.

Kaplan, A. M., \& Haenlein, M. (2010). Users of the world, unite! The challenges andopportunities of social media. Business Horizons, 53, 59-68.

Karlsson, C., Zhang, W. (2001). The role of universities in regional development endogenous human capital and growth in a two-region model. Ann. Regional Sci. 35 (2), 179-197.

Kertajaya, Hermawan, Kotler, Philip. (2017). Marketing 4.0. Moving from traditional to digital. Wiley, Canada.

Kertajaya Hermawan. (2016). Citizen 4.0, Menjejakkan prinsip-prinsip digital pemasaran humanis di era digital. GPU, Jakarta.

Klingberg, T. (2009). The overflowing bra information overload the limits of workingmemory. New York: Oxford University Press.

Kung, L. (2008). Strategic management in the media: Theory to practice. London: Sage.

Lee, H.-K., 2014. Transnational cultural fandom. In: Dutis, L., Zwaan, K., Reijinders, S. (Eds.), Ashgate Research Companion to Fan Cultures. Farnham, UK. Ashgate, pp. 195-206.

Levy, P., \& Birkner, C. (2011). Digital marketing 2011: What you need to know.Marketing News, 45(3), 10-14.

Lowe, B., \& Laffey, D. (2011). Is twitter for the birds? Using twitter to enhance studentlearning in a marketing course. Journal of Marketing Education, 33(2), 183-192.

Mangold, W. G., \& Faulds, D. J. (2009). Social media: The new hybrid element of the promotion mix. Business Horizons,52(4), $357-365$.

McAfee, A., \& Brynjolfsson, E. (2012). Big data: The management revolution. HarvardBusiness Review, October 2012, 60-68.

Michaelidou, N., Siamagka, N., \& Christodoulides, G. (2011).Usage, barriers andmea-surement of social media marketing: An exploratory investigation of small andmedium B2B 
brands. Industrial Marketing Management, 40(7), 1153-1159.

Micu, A. C., Dedeker, K., Lewis, I., Moran, R., Netzer, O., Plummer, J., et al. (2011). Guest editorial: The shape of marketing research in 2021. Journal of AdvertisingResearch, 51(1), 213-221.

Mulhern, F. (2009). Integrated marketing communications: From media channels todigital connectivity. Journal of Marketing Communications, 15(2-3), 85-101.

Nilamsari, N. (2006). Entitas bisnis berbasis teknologi informasi: Analisis terhadap bisnis detikcom. Wacana Jurnal Ilmiah Ilu Komunikasi 5(18), 172-190.
Quinton, S., \& Fennemore, P. (2013). Missing a strategic marketing trick? The useof online social networks by UK charities. International Journal of Nonprofit andVoluntary Sector Marketing, 18, 36-51.

Schlee, R., \& Harich, P. K. R. (2010). Knowledge and skill requirements formarketing jobs in the 21 st century. Journal of Marketing Education, 32(3),341-352.

Valos, M. J., Ewing, M. T., \& Powell, I. H. (2010). Practitioner prognosticationson the future of online marketing. Journal of Marketing Management, 26(3-4),361-376.

https://vtlo.com/creative-communication/what-isa-creative-communication-strategy/ 